\title{
Atol das Rocas: an oasis for Octopus insularis juveniles (Cephalopoda: Octopodidae)
}

\author{
Helena F. Bouth', 2; Tatiana S. Leite ${ }^{1,3}$; Françoise D. de Lima' \& Jorge E. Lins Oliveira' \\ ${ }^{1}$ Laboratório de Biologia Pesqueira, Departamento de Oceanografia e Limnologia, Universidade Federal do Rio Grande do \\ Norte. Via Costeira, Praia de Mãe Luiza, 59014-100 Natal, RN, Brasil. \\ ${ }^{2}$ In memoriam. \\ ${ }^{3}$ Corresponding author. E-mail: leite_ts@yahoo.com.br
}

\begin{abstract}
The habitat, population density, distribution and diet of Octopus insularis Leite \& Haimovici, 2008 were studied in the Atol das Rocas Biological Reserve, based on visual census carried out in fixed quadrants. For each octopus den, we collected data on octopus size, substrate, type of den, and food remains around it. A total of 100 octopus dens were found within the fixed quadrants. The highest density occurred at Mapas area $\left(0.30 \mathrm{inds} / 100 \mathrm{~m}^{2}\right)$ and the lowest at Crista Algálica $\left(0.07\right.$ inds/100 $\mathrm{m}^{2}$ ). The preferred den type was the one on the reef bed $(69 \%)$, reinforcing the importance of rocky substrates for this species. A total of 454 food items, classified into 22 distinct taxa, were collected. The class Crustacea was best represented, accounting for $70.5 \%$ of the total prey, followed by Gastropoda (22.4\%), Bivalvia (6.4\%) and Cephalopoda (0.7\%). Five species represented more than $80 \%$ of all findings: the crabs, Xanthodius denticulatus White, 1848 (38.5\%), Microphrys bicornutus (Latreille, 1825) (18.5\%) and Mithrax forceps Milne-Edwards, 1875 (7.0\%); and the gastropods Hipponix sp. (9.3\%) and Collisella sp. (8.4\%). The overwhelming preference for small crabs shows that $O$. insularis is a specialized predator. The strong presence of juveniles inside the ring reef indicates the importance of this location for the development of this octopus species in northeastern Brazil.
\end{abstract}

KEY WORDS. Diet; habitat; oceanic island; octopus.

Octopuses are soft-bodied epibenthic animals without external protection. Because they are vulnerable, the substrate where these animals choose to settle on, and the den they select for shelter after the paralarval planktonic period (CusHING 1982) have a significant influence on their distribution and survival (Hanlon \& Messenger 1996).

Studies on habitat preferences of octopuses in tropical reefs have shown that a number of characteristics, such as den availability (ARONSON 1986) and preference for reef edges (Forsythe \& Hanlon 1997) affect octopus distribution. These animals are normally solitary and use cracks or crevices in rocks, empty shells, holes in reefs or even sandy-muddy bottoms as refuge sites where they feed and rest (Bоусотт 1954, Woods 1965 , Altman 1967, Mather 1994).

In addition to substrate, den type and the availability of dens, the presence and abundance of suitable prey is another environmental factor that may influence the distribution, abundance and habitat preference of octopuses. Although these cephalopods are able to feed on a wide diversity of prey and are frequently considered generalist predators, studies have shown that the diet of octopuses may be influenced by both food preference and prey availability (HARTwICK et al. 1981, Ambrose 1984, Scheel et al. 2007).

Studies using midden analysis have shown that, regard- less of local prey diversity, only a few species are represented in the diets of octopuses. For instance, the analysis of middens of Enteroctopus dofleini (Wulker, 1910) in Alaska revealed that only five species accounted for more than $80 \%$ of the prey ingested (VINCENT et al. 1998). These results are in agreement with those of Leite et al. (2009b) for the Fernando de Noronha Archipelago, which revealed that only two species of crabs represented more than $50 \%$ of the prey consumed, by Octopus insularis Leite \& Haimovici, 2008, despite the large number of prey species (48) at the remains. This octopus species demonstrated a strong preference for small crustaceans, using a foraging strategy known as "time minimizing" (Stephens \& KReBs 1986).

Although several studies in natural environments, mainly off islands of the Caribbean (Mather 1991), Pacific (Ibanez \& Chong 2008) and Alaska (Scheel et al. 2007), have provided interesting and original results on the ecology and behavior of octopuses, this type of research in Brazil only began in1998, with the Cephalopoda Project. This project conducts research off oceanic islands such as those in the archipelagos of Fernando de Noronha, São Pedro and São Paulo Archipelago, and Atol das Rocas Biological Reserve. The main goal of the project is increasing our knowledge of the diversity, ecology, behavior and conservation of cephalopods that occur in these regions (Leite et al. 2008a, 2009a,b). 
Octopus insularis is the most common octopus species in shallow waters around these oceanic islands and at rocky beaches and reef systems along the northeast coast of Brazil (Leite et al. 2008b). It is a medium-sized octopus with mean mantle length of $120 \mathrm{~mm}$ and total weight of $1.5 \mathrm{~kg}$. Live specimens vary from yellow to reddish brown.

In the present study, which is part of the Cephalopoda project, we analyze the distribution, abundance and diet of $O$. insularis (Leite et al. 2008a) at the Atol das Rocas Biological Reserve, the only atoll in the South Atlantic, and assess the importance of the Atol das Rocas for the development and life cycle of this species.

\section{MATERIAL AND METHODS}

The Atol das Rocas is a Biological Reserve that belongs to the state of Rio Grande do Norte (RN). It is located 144 nautical miles $(267 \mathrm{~km})$ to the east-northeast of the city of Natal, RN, and 80 nautical miles $(148 \mathrm{~km})$ to the west of the Fernando de Noronha Archipelago, in the state of Pernambuco (0350'30"S and $33^{\circ} 49^{\prime} 29^{\prime \prime} \mathrm{W}$ ) (Fig. 1). The area of the Biological Reserve covers $360 \mathrm{~km}^{2}$, including the atoll and surrounding waters up to the $1000 \mathrm{~m}$ isobath (SOAREs-Gomes et al. 2001). The atoll is composed mostly of coralline algae, represented mainly by Porolithon $c f$. pachydermum Foslie, 1909 (SOARes et al. 2009). Vermitid gastropods and hermatypic corals also occur, the latter represented mainly by Siderastrea stellata Verrill, 1868 (GHERARDI \& Bosence 2001). During high tide, the entire atoll is covered with seawater, except for two small islands (Farol and Cemitério). During low tide, the reef flat is exposed, and several pools are formed (PaIva et al. 2007). These pools consist of depressions in the reef and can reach lengths of $150 \mathrm{~m}$ and depths of $7 \mathrm{~m}$. Their bottoms normally consist of carbonate sands. The climate is equatorial, with southeast trade winds and mean temperature of $26^{\circ} \mathrm{C}$. The rainy season extends from March to July, similar to the Fernando de Noronha Archipelago (Gusmão 2005).

Data on distribution and abundance of $O$. insularis were collected using the method of visual censuses for fixed quadrants (KREBS 1999) in six areas of the Atoll (Farol, Cemiterio, Mapas, Salão, Crista Algálica and Âncoras) (Fig. 2). Sampling was conducted during six expeditions to Atol das Rocas: September, 2003; January and November, 2004; April, 2005; November, 2007; and July, 2008.

Sampling was conducted in $50 \times 50 \mathrm{~m}\left(2500 \mathrm{~m}^{2}\right)$ quadrants, marked with buoys and subdivided into 25 smaller quadrants measuring $10 \times 10 \mathrm{~m}\left(100 \mathrm{~m}^{2}\right)$ (Leite et al. 2009a). Octopus dens, identified by the simultaneous presence of octopuses and food remains, were marked with numbered buoys.

The octopuses were classified into one of four size categories based on the length of the mantle (ML): extra-small (ES), ML less than or equal to $50 \mathrm{~mm}$; small (S), ML between 51 and $80 \mathrm{~mm}$; medium (M), ML between 81 and $100 \mathrm{~mm}$; and large (L), ML greater than $100 \mathrm{~mm}$. The ES and S octopuses were

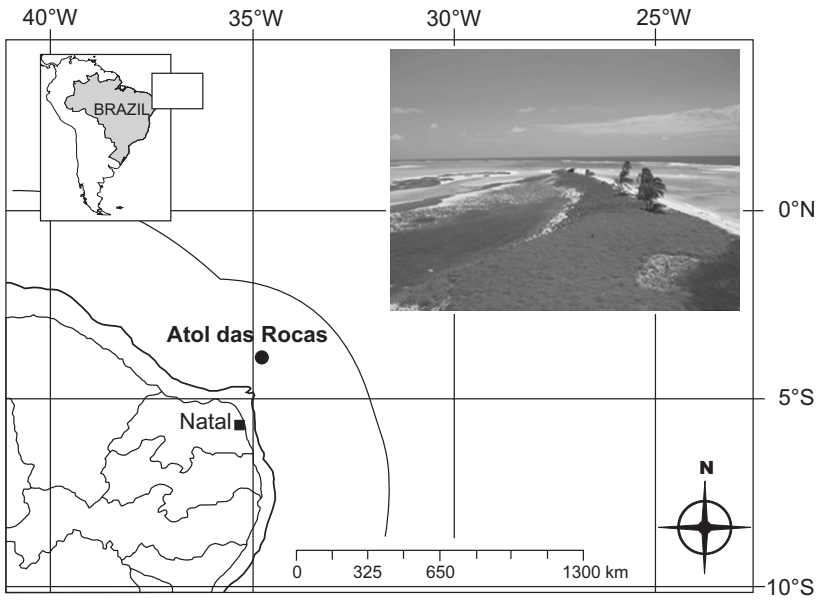

Figure 1. Location of Atol das Rocas, Rio Grande do Norte, Brazil.

considered juveniles, at gonadal stage I (ML $<65 \mathrm{~mm})$ or subadults, at stage II (ML up to $80 \mathrm{~mm}$ ) (T.S. Leite unpubl. data).

The occupied dens were classified into one of four categories: 1) Den on reef bed, octopus sheltered in a natural hole on reef bed without modification; 2) Horizontal Crevice, octopus sheltered in a crevice on hard substrate with signs of modification, like sand or rubble around it; 3) Vertical Crevice, octopus sheltered in a crevice perpendicular to the hard substrate; and 4) Unconsolidated Substrate, octopus sheltered between rock and sand (LeITe et al. 2009a). Sampling took place only at low tides, due to better den visibility.

In the diet analysis, we considered the middens found in the dens occupied by octopuses both inside and outside the fixed quadrants (Leite et al. 2009a). The items were preserved in formaldehyde for subsequent identification at the lowest possible taxonomic level. Only recent remains, which had no algae growing on the inner surfaces of shells and carapaces, were taken into account.

The remains collected were analyzed in the laboratory with the help of a loupe and identified based on reference texts (Rios 1994, Melo 1996). The lengths and widths (in millimeters) of the bivalve, gastropod shells and crab carapaces were measured with a pachymeter.

Statistics 7 and SPSS software were used for data analysis and statistical testing. The following statistical tests were performed: Student's t-test, one-way ANOVA, with post hoc tests (Unequal N) when necessary, contingency tables (contingency coefficient) and normality test. All the statistical tests were considered significant with $\mathrm{p}<0.05$.

\section{RESULTS}

Octopus insularis was found on the reef ring of the Atol das Rocas or in inner pools whose high tide did not exceed $2.6 \mathrm{~m}$. The substrates where the octopuses occurred were char- 


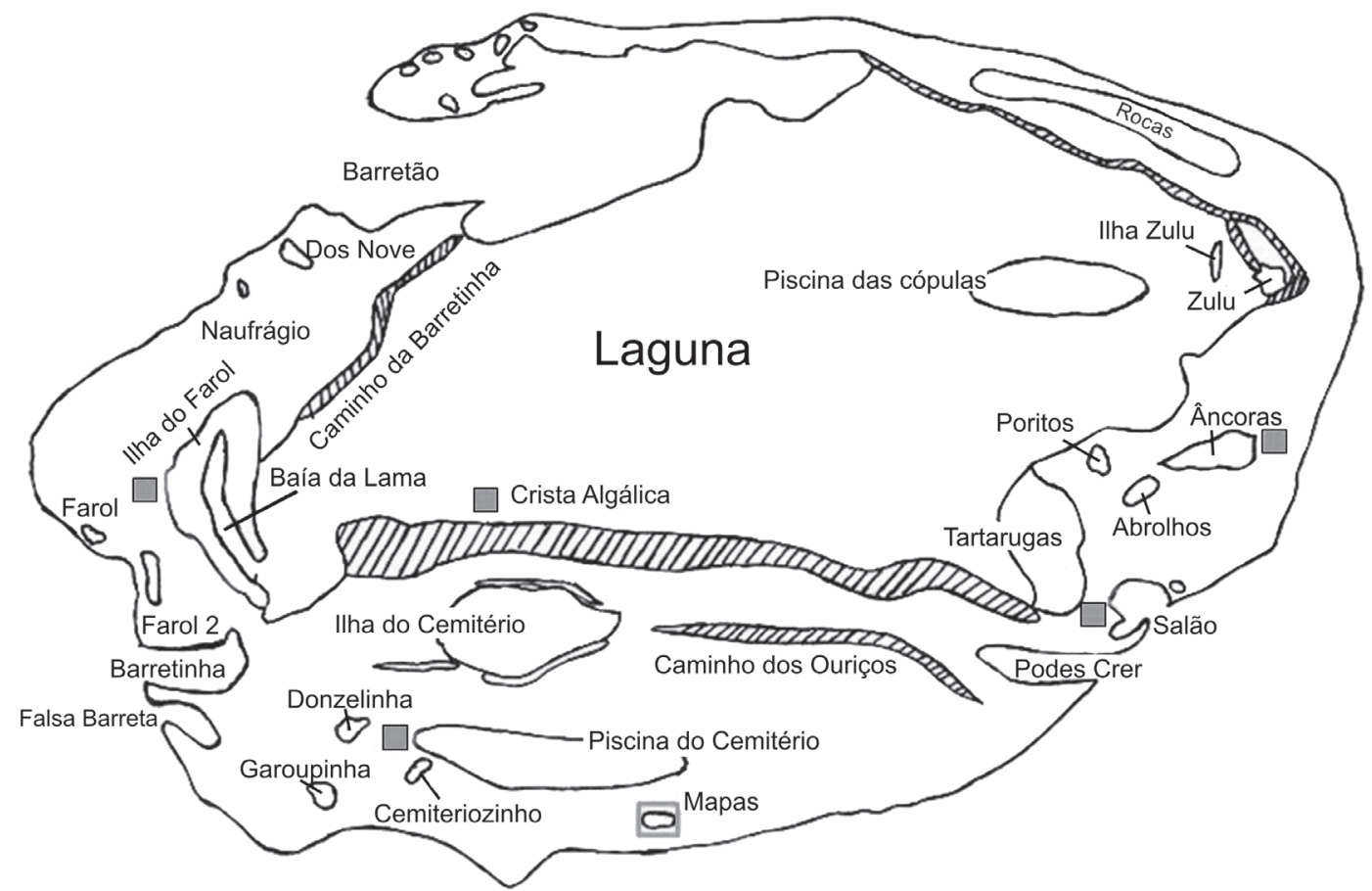

Figure 2. Map of the Atol das Rocas, with squares indicating the location of the sample areas.

acterized by the presence of calcareous algae and corals, the main atoll-forming organisms (КІкUсні 2002) (Tab. I).

Sampling yielded a total of 133 octopuses, of which 100 (16 extra small, 59 small, 14 medium and 11 large) occurred in the quadrants. Other 33 were observed outside the quadrants during walks on the reef ring or in the tide pools formed during low tide.

The mean density inside the sampled areas ranged from 0.07 individuals $/ 100 \mathrm{~m}^{2}$ (Crista Algálica) to 0.30 individuals/ $100 \mathrm{~m}^{2}$ (Mapas), with an over-all mean of $0.18 \mathrm{ind} / 100 \mathrm{~m}^{2}$ (Tab. II). The mean density varied from 0.16 to $0.36 \mathrm{ind} / 100 \mathrm{~m}^{2}$ in the rainy season $\left(\mathrm{M}=0.24 \mathrm{ind} / 100 \mathrm{~m}^{2}\right)$ and from 0.04 to 0.24 ind $/ 100 \mathrm{~m}^{2}\left(\mathrm{M}=0.15 \mathrm{ind} / 100 \mathrm{~m}^{2}\right)$ during the dry season (Tab. II), but these variations were not statistically significant (t-test, $\mathrm{p}>0.05)$.
Considering the four size categories, overall distribution was normal, with most octopuses classified into the intermediate category, defined as small $(\mathrm{S})\left(\chi^{2}=50.80, \mathrm{df}=3, \mathrm{p}<0.0001\right)$ $(\mathrm{N}=59)$ (Fig. 3).

The small and extra-small octopuses occurred with more frequency in the rainy season, when $90 \%(\mathrm{~N}=53)$ of the animals were classified into these two categories. The medium and large octopuses were most frequent in the dry season $(76 \%$, $\mathrm{N}=19$ ) (Contingency table: Contingency coefficient $=0.381$ $(4 \times 2) ; \mathrm{df}=3 ; \mathrm{p}<0.05$ ) (Fig. 4).

Among the four den types, the vertical crevice was the least occupied $(\mathrm{N}=4)$, whereas the den on the reef bed was the most $(\mathrm{N}=69)$, with no differences in relation to [octopus] size (Contingency table, $\mathrm{p}>0.05$ ). There was also no significant correlation between size and sample areas (Contingency table, $\mathrm{p}<0.05$ ).

Table I. Description of habitats of the six sampled areas in Rocas Atoll.

\begin{tabular}{ll}
\hline \multicolumn{1}{c}{ Area } & \multicolumn{1}{c}{ Description } \\
\hline Âncoras & Reef bed containing tidepools with hard substrate bottoms, presence of algae \\
Cemitério & Reef bed containing tidepools with sandy bottoms \\
Crista Algálica & Relatively dry reef bed, presence of numerous algae \\
Farol & Reef bed, very rocky and tidepools containing sandy bottoms \\
Mapas & Reef bed near the edge of the ring, presence of numerous algae and tidepools with sandy bottoms \\
Salão & Reef bed with tidepools and numerous algae \\
\hline
\end{tabular}



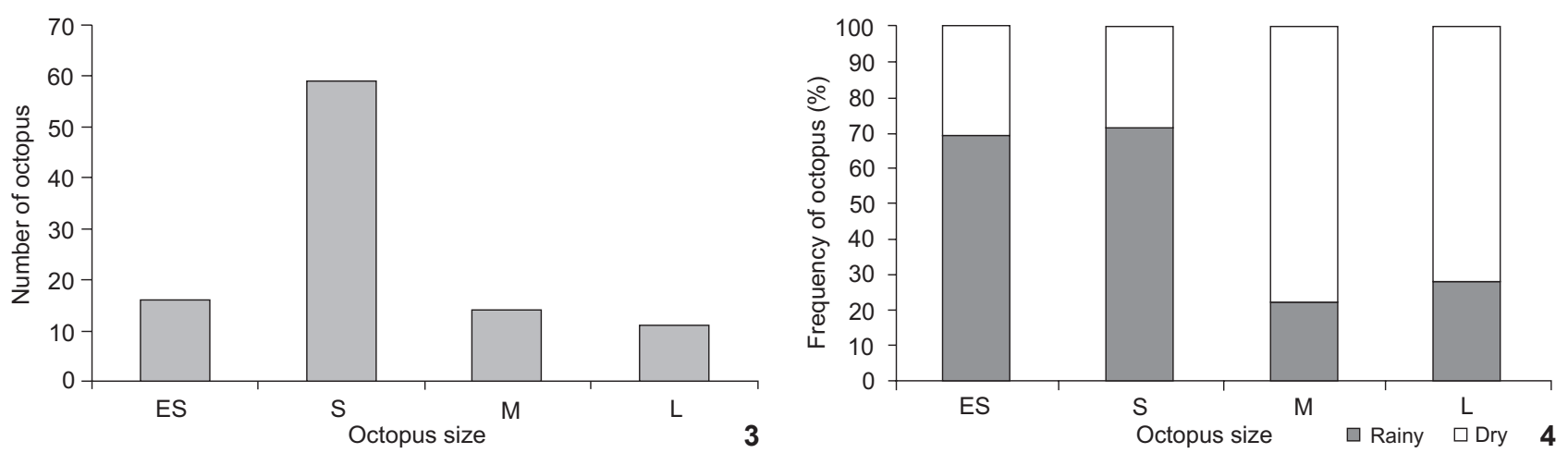

Figures 3-4. (3) Total number of Octopus insularis found on Atol das Rocas, distributed among the four size categories. (4) Frequency of octopuses in the four size category (Octopus insularis) in relation to season of the year sample areas of Atol das Rocas.

Table II. Mean density of O. insularis by sample area and by season of the year, between 2003 and 2008, in the Rocas Atoll Biological Reserve.

\begin{tabular}{|c|c|c|c|c|c|}
\hline Area & Mean (ind/100 $\mathrm{m}^{2}$ ) & Rainy (ind/100 m²) & $\mathrm{N}$ & Dry (ind/100 m²) & $\mathrm{N}$ \\
\hline Cemitério & 0.20 & 0.25 & 3 & 0.10 & 2 \\
\hline Crista Algálica & 0.07 & 0.12 & 1 & 0.04 & 2 \\
\hline Âncoras & 0.24 & 0.24 & 1 & 0.24 & 1 \\
\hline Farol & 0.18 & 0.28 & 2 & 0.12 & 3 \\
\hline Mapas & 0.30 & 0.36 & 1 & 0.24 & 1 \\
\hline Salão & 0.17 & 0.16 & 2 & 0.18 & 3 \\
\hline Mean & 0.18 & 0.24 & & 0.15 & \\
\hline
\end{tabular}

A total of 454 items were found in the middens of 110 dens and classified into four taxa: Crustacea $(70.5 \% \mathrm{~N}=320)$, Gastropoda $(22.5 \% \mathrm{~N}=102)$, Bivalvia ( $\% \mathrm{~N}=6.3 \%, \mathrm{~N}=29)$ and Cephalopoda $(0.7 \% \mathrm{~N}=3)$. Only five species accounted for more than $80 \%(\mathrm{~N}=371)$ of all findings: the crabs Xanthodius denticulatus White, 1848 (38.5\%), Microphrys bicornutus (Latreille, 1825) (18.5\%) and Mithrax forceps Milne-Edwards, 1875 (7\%), and the gastropods Hipponix sp. (9.3\%) and Collisella sp. (8.4\%) (Tab. III). With respect to the relative presence of prey classes in each area, the Crustaceans were more common at Crista Algálica (38.75\% of $\mathrm{N}=320$ ) followed by Cemitério (22.5\%), whereas Bivalvia and Gastropoda were found mainly at Cemitério (Bivalvia, $62.07 \%$ of $\mathrm{N}=29$ and Gastropoda, $39.21 \%$ of $\mathrm{N}=102$ ) (Fig. 5). Cephalopoda was not included in this analysis because it was represented by only a few individuals $(\mathrm{N}=3)$.
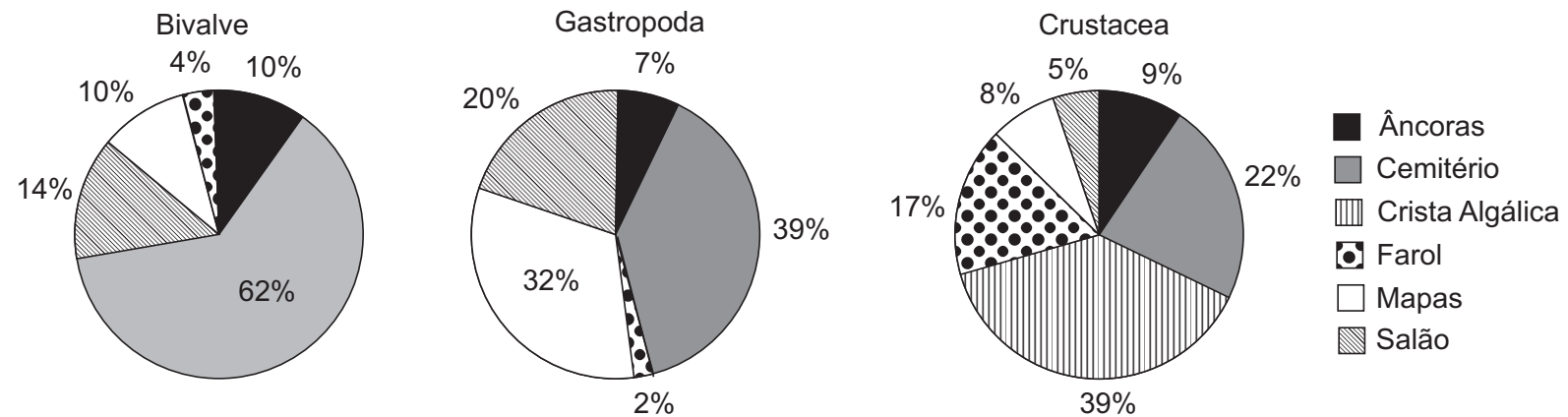

Figure 5. Frequency of occurrences of the food remains (Crustacean, Gastropoda and Bivalve) identified in the dens of Octopus insularis, in relation to the sample areas of Atol das Rocas. 
Table III. Prey of $O$. insularis $(n=473)$ found in the middens on Rocas Atoll, between 2003 and 2008 .

\begin{tabular}{|c|c|c|c|c|c|}
\hline Taxon & Species & Total number & $\%$ & Occurrence in dens & $\%$ occurrence \\
\hline Crustacea & Xanthodius denticulatus & 175 & 38.5 & 58 & 53.2 \\
\hline Crustacea & Microphrys bicornutus & 84 & 18.5 & 36 & 33.0 \\
\hline Gastropoda & Hipponix sp. & 42 & 9.3 & 17 & 15.6 \\
\hline Gastropoda & Collisella sp. & 38 & 8.4 & 22 & 20.2 \\
\hline Crustacea & Mithrax forceps & 32 & 7.0 & 15 & 13.8 \\
\hline Bivalvia & Chione intapurpurea & 18 & 4.0 & 5 & 4.6 \\
\hline Crustacea & Mithrax verrucosos & 14 & 3.1 & 9 & 8.2 \\
\hline Crustacea & Teleophrys pococki & 10 & 2.2 & 7 & 6.4 \\
\hline Gastropoda & Fissurella rósea & 9 & 2.0 & 7 & 6.4 \\
\hline Gastropoda & Astraea tecta olfersii & 6 & 1.3 & 2 & 1.8 \\
\hline Bivalvia & Brachidontes exustus & 5 & 1.1 & 2 & 1.8 \\
\hline Bivalvia & Species 1 & 4 & 0.9 & 2 & 1.8 \\
\hline Crustacea & Calappa ocellata & 3 & 0.7 & 3 & 2.7 \\
\hline Gastropoda & Leucozonia nassa & 3 & 0.7 & 3 & 2.7 \\
\hline Cephalopoda & Octopus sp. & 3 & 0.7 & 3 & 2.7 \\
\hline Bivalvia & Codakia orbicularis & 2 & 0.4 & 2 & 1.8 \\
\hline Crustacea & Calappa gallus & 1 & 0.2 & 1 & 0.9 \\
\hline Crustacea & Carpilius corallinus & 1 & 0.2 & 1 & 0.9 \\
\hline Gastropoda & Cypraea cynerea & 1 & 0.2 & 1 & 0.9 \\
\hline Gastropoda & Species 1 & 1 & 0.2 & 1 & 0.9 \\
\hline Gastropoda & Nassarius albus & 1 & 0.2 & 1 & 0.9 \\
\hline Gastropoda & Volvarina sp. & 1 & 0.2 & 1 & 0.9 \\
\hline
\end{tabular}

The total number of prey remains in octopus dens per expedition varied from 1 to 66 - Mean $(M)=18.16$ and Standard Deviation $(\mathrm{SD})=18.21-$ among the sample areas. The greatest mean value was found for dens at Crista Algálica $(\mathrm{M}=$ 31 from 14 dens $)$ and the smallest at Salão $(M=9.5$, from 13 dens).

The number of prey species identified per den (richness) among the sampling areas varied from 1 to 10 , and the total density of prey per den ranged from 1 to $37(\mathrm{M}=4$ and $\mathrm{SD}=4.7)$. The large octopuses left the largest number of remains $(\mathrm{M}=9.9$ remains/octopus), followed by medium-sized individuals ( $\mathrm{M}=7.9$ remains/octopus), small ( $\mathrm{M}=3.3$ remains/octopus) and finally extra-small animals ( $\mathrm{M}=2.4$ remains/octopus). With the exception of the extra-small octopuses, crustaceans were the prey most consumed by octopuses in all size categories: small (56.4\%), medium $(90.0 \%)$ and large $(92.5 \%)$. Only the extra small octopuses consumed more gastropods (61.5\%) (Fig. 6).

Only two main species were used in the analysis of prey size variation in relation to octopus size, $X$. denticulatus and $M$. bicornutus, given that these species accounted for more than $50 \%$ of the total remains. These two crab species showed significant differences in carapace width $(\mathrm{CW})(X$. denticulatus:

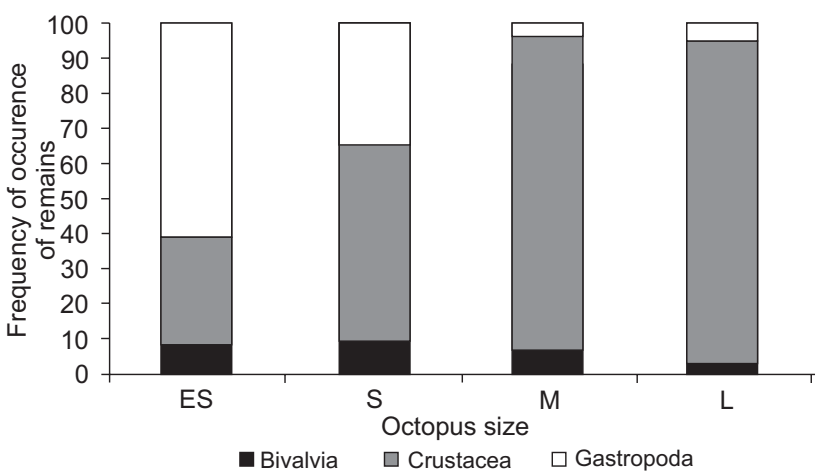

Figure 6. Frequency of occurrences of the food remains (Crustacean, Gastropoda and Bivalve) identified in the dens of Octopus insularis, in relation to the four octopus sizes categories.

CW, 4 to $34 \mathrm{~mm}$; $\mathrm{M}=18.5 \mathrm{~mm}$; $\mathrm{N}=175$; and $M$. bicornutus: CW, 8 to $23 \mathrm{~mm}$; $\mathrm{M}=14.1 \mathrm{~mm}$; $\mathrm{N}=84$ ) (t-test, $\mathrm{p}<0.05$ ). The greatest size frequency found for M. bicornutus was between 10 and $16 \mathrm{~mm}$ wide, whereas most of the $X$. denticulatus had carapace width between 16 and $22 \mathrm{~mm}$ (Fig. 7). 


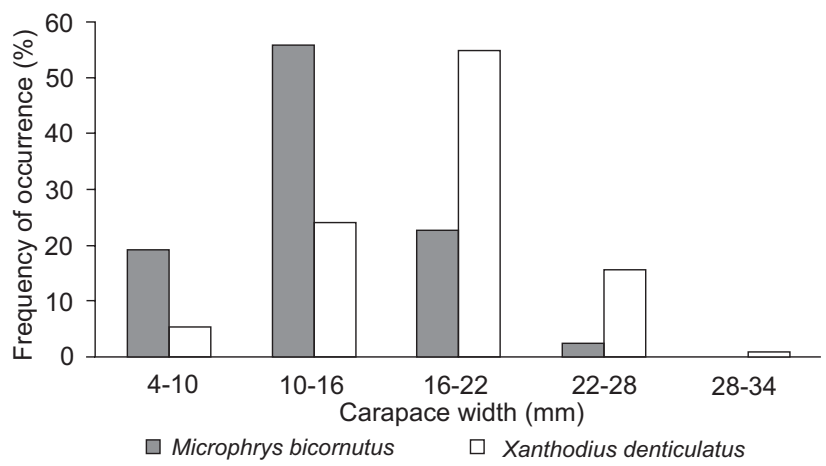

Figure 7. Carapace size distribution of the two main prey species (Xanthodius denticulatus and Microphrys bicornutus) identified in the food remains of Octopus insularis dens, at Atol das Rocas.

The mean width of $X$. denticulatus carapaces in relation to octopus size (Extra Small, $\mathrm{M}=19.2 \mathrm{~mm}$; Small, $\mathrm{M}=17.1 \mathrm{~mm}$; Medium, $\mathrm{M}=18.9 \mathrm{~mm}$; Large, $\mathrm{M}=20.0 \mathrm{~mm}$ ) was significantly different when small and large octopuses were compared (ANOVA, $\mathrm{F}=647.39 ; \mathrm{df}=1 ; \mathrm{p}<0.05$; Post hoc test, $\mathrm{df}=171.00$; MS = 19.714). For M. bicornutus, a slight increase in average prey carapace width was not associated with a significantly greater octopus size (Extra Small, $\mathrm{M}=12.5 \mathrm{~mm}$; Small, $\mathrm{M}=13.2$ mm; Medium, $\mathrm{M}=14.00 \mathrm{~mm}$; Large, $\mathrm{M}=16.0 \mathrm{~mm}$ ) according to the results of the post hoc test. This relationship, however, was significant based on the ANOVA $(\mathrm{F}=1577.49$; $\mathrm{df}=1$; $\mathrm{p}<0.05)$.

\section{DISCUSSION}

The abundance of juveniles of $O$. insularis inside the ring of the Atol das Rocas indicates that this environment offers plenty of shelter for the development of the early life stages of this octopus. The substrate of the reef bed has many natural holes and dens (KiкUchi 2002, Paiva et al. 2007) that can be used for that purpose. Additionally, the great numbers of juveniles inside this biological reserve may also be a result of the abundance of favorite food items, such as the small crustaceans that live inside the reef's hard substrate.

Two other factors may also account for the strong presence of $O$. insularis juveniles inside the Atol das Rocas. First, the area surrounding the entire Atoll is protected and fishing is forbidden (Law 83.549, of July 5, 1978); second, other octopus species are rare in the area, decreasing competition for resources and habitat (Leite \& Haimovici 2006). The Atoll has been described as a breeding and nursery ground for different marine species, such as the lemon shark (Wetherbee et al. 2007) and the green turtle (Marcovaldi \& Marcovaldi 1999), in addition to sheltering the largest marine bird population in the country (Schulz Neto 1998). According to this study, Atol das Rocas can also be considerate a nursery for $O$. insularis.
The relative abundance of $O$. insularis found for the fixed quadrants of the Atol das Rocas was similar to that found for Fernando de Noronha (0.12 to 0.88 ind. $/ 100 \mathrm{~m}^{2}$ ) (Leite et al. 2009a), confirming that $O$. insularis is relatively more abundant than other octopus species (LeITE \& HAIMOVICI 2006) in the shallow warm waters of northeastern Brazil. The elevated density of this species in tropical islands can be confirmed when compared with other studies from subtropical and temperate regions, such as E. dofleini in Alaska (0.072 to 0.085 ind/100 $\left.\mathrm{m}^{2}\right)$ (SCHeEL et al. 2007) and Octopus vulgaris Cuvier 1797, in Greece ( 0 to 0.34 ind $/ 100 \mathrm{~m}^{2}$ ) (Katsanevakis \& Verriopoulos 2004). This difference could be associated with a restricted availability of the preferred substrates and niche restrictions off oceanic islands, which may increase the concentrations at the available habitats. Another explanation, as mentioned above, is the presence of protected areas around the Fernando de Noronha Archipelago and Atoll das Rocas

The small variations in density among the sampled areas within the reef ring of the atoll is likely due to the relatively homogenous substrate, with slight variations only in the number and size of crevices and tide pools that serve as shelter. The slightly greater number of individuals observed at the Mapas, Âncoras and Cemitério areas could reflect the deeper tide pools, which provide more water-filled dens, thereby reducing the possibility of den exposure at low tide. By contrast, the lower population densities at Crista Algálica area may result from its greater distance from the edge of the ring, and sun exposure for longer periods, what causes tide pools and crevices to dry out.

Although relative abundance of $O$. insularis did not vary between the two sampling seasons, consistent with the results obtained by LerTe et al. (2009a) for the same species in Fernando de Noronha, smaller individuals were more common in the rainy season, whereas medium-sized and large individuals were more frequent in the dry season. This difference may be related to favoring the rainy season for reproduction. Rain is also cited as probable factor that could affect benthonic larval supply and attachment to the substrate at tropical environment (Lopez \& Coutinho 2008).

The concentration of octopuses in dens on the reef bed confirms the importance of rocky substrates for the distribution of juveniles of $O$. insularis (LeITE et al. 2009a). It is important to consider that adult octopuses often modify their dens, collecting shells and rocks (Woods 1965, MatHER 1994), whereas juvenile octopuses prefer dens that are ready-to-use, such as the crevices found on the reef bed.

Octopus insularis in Atol das Rocas favored small crabs and mollusks, confirming that this species uses the foraging strategy known as "time minimizing" (Stephens \& Krebs 1986), as described by Leite et al. (2009b) for this octopus at the Fernando de Noronha Archipelago.

A preference for crustaceans was also observed in other species of octopus, such as Octopus maorum Hutton, 1880, in Tasmania (Grubert et al. 1999), and E. dofleini, in Alaska (Dodge 
$\&$ Scheel 1999). This preference may reflect both the ease with which octopuses manage to open shells of small crustaceans and their high energy content (SCHEel et al. 2007). Shells of bivalves and gastropods, on the other hand, cannot be opened as easily by octopuses and require more handling time (STEER \& Semmens 2003).

Similar to the results found for O. vulgaris in South Africa (Sмітн 2003), Enteroctopus megalocyathus (Gould, 1852) in Chile (Ibanez \& Chong 2008) and O. insularis at the Fernando de Noronha Archipelago (Leite et al. 2009b), the size of the crustaceans preyed by $O$. insularis in Atol das Rocas varied only by a few millimeters in relation to the size of the octopus. The extra-small octopuses preferred smaller gastropods, whereas octopuses from other size categories preferred crustaceans. Small gastropods can be more easily captured by smaller octopuses because they do not move with the same agility as crustaceans.

The total number of prey species $(\mathrm{N}=22)$ found in the middens is low when compared with the results of other studies: 48 species are consumed by O. insularis, at the Fernando de Noronha Archipelago (Leite et al. 2009b); 34 species by $E$. dofleini, in Alaska (Vincent et al. 1998); and 39 species by $O$. vulgaris, in South Africa (Sмітн 2003). This difference was probably due to the use of more than one food analysis technique (SмITH 2003), or because samples were taken at different depths (VINCENT et al. 1998, LeiTe et al. 2009b) Moreover, the atoll covers a small area compared with the areas of other study sites.

Although prey preference seems to be one of the factors influencing octopus distribution and abundance (GUERRA 1981, Leite et al 2009a,b), our results do not indicate that the density of $O$. insularis among the sampled areas varied significantly with prey availability. For instance, Crista Algálica had the lowest octopus densities, even though it had the second greatest amount of remains. Because this area is located in the central portion of the atoll, it is more exposed to drying and does not have a constant current, a factor that causes midden piles to be carried away, far from the dens (Ambrose 1983, Mather 1991).

On the other hand, substrate uniformity in the inner area of the atoll, composed basically of incrusting coralline algae and, to a lesser extent, foraminifers, gastropod shells and corals (Oliveira Filho \& Ugadim 1976), could offer an explanation for the low prey diversity in the dens of the different areas sampled.

\section{ACKNOWLEDGMENTS}

The co-authors dedicate this paper in memoriam of the biologist Helena F. Bouth. This testifies our gratitude to her hard work and dedication to marine biological research. We thank Maurizélia Brito and IBAMA for the logistical support at Atol das Rocas; Risonaldo Dantas for helping during the research; Breno Dutra for helping at the very beginning of this study; and Jennifer Mather, for careful review of this manuscript.

\section{LITERATURE CITED}

Altman, J.S. 1967. The behaviour of Octopus vulgaris Lam. in its natural habitat: a pilot study. Report of the Underwater Association of Malta 1966-1967, p. 77-83.

Ambrose, R.F. 1983. Midden formation by octopuses: the role of biotic and abiotic factors. Marine Behavior \& Physiology 10: $137-144$.

Ambrose, R.F. 1984. Food preferences, prey availability, and the diet of Octopus bimaculatusVerrill. Journal of Experimental Marine Biology and Ecology 77: 29-44.

Aronson, R.B. 1986. Life history and den ecology of Octopus briareus Robson in a marine lake. Journal of Experimental Marine Biology and Ecology 95: 37-56.

Воусотт, В.В. 1954. Learning in Octopus vulgaris and other cephalopods. Marine Ecology PublStazZool Napoli 25: 6793.

Cushing, D.H. 1982. Climate and fisheries. London, Academic Press, 373p.

Dodge, R. \& D. Scheel. 1999. Remains of the prey - recognizing the midden piles of Octopus dofleini (Wülker). The Veliger 42: $260-266$.

Forsythe, J.W. \& R.T. HANlon. 1997. Foraging and associated behaviour by Octopus cyanea, 1849 on a coral atoll, French Polynesia. Journal of Experimental Marine Biology and Ecology 209: 15-31.

Gherardi, D.F.M. \& D.W.J. Bosence. 2001. Composition and community structure of the coralline alga reefs from Rocas Atoll, South Atlantic, Brazil. Coral Reefs 19 (3): 205-219.

Grubert, M.A.; V. Awadley \& R.W.G. White. 1999. Diet and feeding strategy of Octopus maorum in southeast Tasmania. Bulletin of Marine Science 65: 441-451.

GuERRA, A. 1981. Spatial distribution pattern of Octopus vulgaris. Journal of Zoology London 195: 133-146.

GusMão, L.G.S. 2005. Nossas ilhas oceânicas, p. 64-131. In: P.T. Chaves; F.H.V. Hazin; J.E.B. Souza \& L.G.S. Gusmão (Eds). O Mar no Espaço Geográûco Brasileiro. Brasília, Ministério da Educação, vol. 8, 304p.

Hanlon, R.T. \& J.B. Messenger. 1996. Cephalopods Behaviour. Great Britain, Cambridge University Press, 231p.

Hartwick, B.; L. Tulloch \& S. MacDonald. 1981. Feeding and growth of Octopus dofleini (Wulker). The Veliger 24 (2): 129138.

Ibanez, C.M. \& J.V. Chong. 2008. Feeding ecology of Enteroctopus megalocyathus (Cephalopoda: Octopodidae) in southern Chile. Journal of the Marine Biological Association of the United Kingdom 88 (4): 793-798.

KatsaneVAKIS, S. \& G. VerRiopoulos. 2004. Den ecology of Octopus vulgaris Cuvier, 1797, on soft sediment: availability and types of shelter.Scientia Marina 68 (1): 147-157.

KIKUCHI, R.K.P. 2002. Atol das Rocas, Litoral do Nordeste do Brasil - Único atol do Atlântico Sul Equatorial Ocidental. In: C. Schobbenhaus; D.A. Campos; E.T. QueIroz; M. Winge \& M.L.C. 
Berbert-Born. (Eds). Sítios Geológicos e Paleontológicos do Brasil. Brasilia, DNPM/CPRM (SIGEP), 390p.

Krebs, C.J. 1999. Ecological Methodology. Menlo Park, Benjamin Cummings, 624p.

Leite T.S. \& M. Haimovici. 2006. Presente conhecimento da biodiversidade e habitat dos polvos (Cephalopoda: família Octopodidae) de águas rasas das ilhas oceânicas do nordeste brasileiro, p. 199-214. In: R.J.V. Alves \& J.W.A. CASTRo (Eds). Ilhas Oceânicas Brasileiras - da Pesquisa ao Manejo. Brasília, Ministério do Meio Ambiente, 298p.

Leite, T.S.; M. Haimovici \& J.E. Lins Oliveira. 2008a. A pesca de polvos no Arquipélago de Fernando de Noronha, Brasil. Boletim do Instituto de Pesca 34 (2): 271-280.

Leite, T.S.; M. Haimovici; W. Molina \& K. Warnke. 2008b. Morphological and genetic description of Octopus insularis, a new cryptic species in the Octopus vulgaris complex (Cephalopoda: Octopodidae) from the tropical southwestern Atlantic. Journal of Molluscan Studies 74: 63-74.

Leite, T.S.; M. Haimovici; J. Mather \& J.E. Lins Oliveira. 2009a. Habitat, distribution, and abundance of the commercial octopus (Octopus insularis) in a tropical oceanic island, Brazil: Information for management of an artisanal fishery inside a marine protected area. Fisheries Research 98: 85-91.

Leite, T.S.; M. Haimovici \& J. Mather. 2009b. Octopus insularis (Octopodidae), evidences of a specialized predator and a time-minimizing hunter. Marine Biology 156: 2355-2367.

Lopez, M.S. \& R. Coutinho. 2008. Acoplamento plâncton-bentos: o papel do suprimento larval na estrutura das comunidades bentônicas de costões rochosos. Oecologia Brasiliense 12 (4): 575-601.

Marcovaldi, M.A. \& G.G. Marcovaldi. 1999. Marine turtles of Brazil: the history and structure of Projeto TAMAR-IBAMA. Biological Conservation 91: 35-41.

Mather, J.A. 1991. Foraging, feeding and prey remains in midden of juveniles Octopus vulgaris (Mollusca: Cephalopoda). Journal of Zoology London 224: 27-39.

Mather, J.A. 1994. Home choice and modification by juvenile Octopus vulgaris (Mollusca: Cephalopoda): specialized intelligence and tool use. Journal of Zoology London 233: 359-368.

Melo, G.A.S. 1996. Manual de Identificação dos Brachyura (Caranguejos e Siris) do Litoral Brasileiro. São Paulo, Plêiade/FAPESP, 604p.
Oliveira Filho, E.C. \& Y. Ugadim. 1976. A survey of the marine algae of the Atol das Rocas (Brazil). Phycologia 15 (1): 4144.

Paiva, P.C.; P.S. Young \& C.A. Echeverría. 2007. The Rocas Atoll, Brazil: a preliminary survey of the crustacean and polychaete fauna. Arquivos do Museu Nacional Rio de Janeiro 65 (3): 241-250.

RIos, E. 1994. Seashells of Brazil. Rio Grande, Editora da FURG, $2^{\text {nd }}$ ed., $481 p$.

Scheel, D.; A. Lauster \& T.L.S. Vincent. 2007. Habitat ecology of Enteroctopus dofleini from middens and live prey surveys in Prince William Sound, Alaska, p 434-458. In: N.H. Landman; R.A. Davis; R.H. Mapes (Eds). Cephalopods Present and Past: New insights and fresh Perspectives. New York, Springer, 482p.

Schulz Neto, A. 1998. Aspectos biológicos da avifauna na Reserva Biológica do Atol das Rocas, Rio Grande do Norte, Brasil. Hornero 1: 8-19.

SмIтн, C.D. 2003. Diet of Octopus vulgaris in False Bay, South Africa. Marine Biology 143: 1127-1133.

Soares-Gomes, A.; R.C. Villaça \& C.A.C. Pezzella. 2001. Atol das Rocas ecossistema único no Atlântico Sul. Ciência Hoje 29 (172): 32-39.

Soares, M.O.; V.B. Lemos \& R.K.P. KikUchi. 2009. Atol das Rocas, Atlântico Sul Equatorial: considerações sobre a classificação do recife biogênico. Revista Brasileira de Geociências 39 (2): 238-243

Steer, M.A. \& J.M. Semmens. 2003. Pulling or drilling, does size or species matter? An experimental study of prey handling in Octopus dierythraeus (Norman, 1992). Journal of Experimental Marine Biology and Ecology 290: 165-78.

Stephens, D.W. \& J.R. Krebs. 1986. Foraging Theory. Princeton, Princeton University Press, $247 \mathrm{p}$.

Vincent, T.L.S.; D. Scheel \& K.R. Hough. 1998. Some aspects of diet and foraging behavior of Octopus dofleini (Wülker, 1910) in its Northernmost Range. Marine Ecology 19 (1): 13-29.

Wetherbee, B.M.; S.H. Gruber \& R.S. Rosa. 2007. Movement patterns of juvenile lemon sharks Negaprionbrevirostris within Atol das Rocas, Brazil: a nursery characterized by tidal extremes. Marine Ecology Progress Series 343: 283-293.

Woods, J. 1965. Octopus watching off Capri. Animals 7: 324327.

Submitted: 12.I.2010; Accepted: 13.XI.2010.

Editorial responsibility: Paulo da C. Lana 